\title{
Macromedia Flash Based Learning Media Development to Improve Spatial Student Ability
}

\author{
Sri Ayu Azriati ${ }^{1} \quad$ Edi Syahputra $^{2} \quad$ Sumarno $^{2}$ \\ 1.Graduate Program School in Mathematics Education, State University of Medan, \\ Jl. Williem Iskandar Psr. V M edan Estate, 20221, Sumatera Utara, Indonesia \\ 2.Department of Mathematics Education, State University of Medan, Jl. Williem Iskandar Psr. V \\ Medan Estate, 20221, Sumatera Utara, Indonesia
}

\begin{abstract}
The use of media in learning can facilitate students in understanding something abstract to be more concrete. This study aims to describe: 1) The validity, practicality, and effectiveness of learning media based on Macromedia flash mathematics developed; 2) Improving students' spatial ability by using learning media based on Macromedia flash that was developed. This research is development research. This research was carried out through two stages, namely the stage of developing learning media based on Macromedia flash mathematics using the 4-D development model, and the stage of testing the learning media of learning based on Macromedia flash developed in class XIIMIA-1 and XIIMIA-2 SMA Negeri 1 Batang Kuis. From the results of trial I and trial II obtained: 1) The validity of the learning media developed was valid, the practicality of the learning media had met the practical criteria in terms of a) The validity of the learning media according to experts; b) The practicality test questionnaire of the mathematics learning media developed belongs to the practical category with a minimum score of $76 \%$ and the effectiveness of the learning media has met the effective criteria in terms of a) Classical student completeness of learning; b) Ideal use of time. 2) An increase in students' spatial ability in the first try is 66.67 increased to 77.5 in the second trial.
\end{abstract}

Keywords: Development of Mathematics Learning Media, Macromedia Flash, Spatial Ability

DOI: $10.7176 / \mathrm{JEP} / 11-3-14$

Publication date: January $31^{\text {st }} 2020$

\section{Introduction}

The uses of technology in the field of education requires educators to be more creative and innovative to utilize technology as an effort to improve the quality of education in order to achieve learning objectives. According to Marliani (2015) to advance this science and technology also require an understanding of mathematics that is strong from an early age. The role of learning media in the learning and teaching process is a unity that cannot be separated from the world of education. Learning media are all things that can be used to channel the sender's message to the recipient so that it can stimulate the thoughts, feelings, attention, and interests of students to learn (Tafanao, 2018). Learning media play an important role in the learning process so that it can improve the quality of education. In addition, the use of instructional media in the process of learning mathematics can arouse students' motivation and interest in learning independently.

The classic problem that we often encounter in the world of education, especially in mathematics, is the negative response to mathematics. Students assume that mathematics is a scary subject compared to other subjects. Indirectly, these opinions cause them to be lazy to try to understand the concepts contained in mathematics. As said by Irwanto (2017) in his research students in class VIII have difficulty when studying mathematics, especially material related to spatial or geometry, because students learn these materials only through books and learning media in schools less attractive to students.

Currently, teachers are required to be able to apply learning methods that are more student centers. In the learning desired by the teacher is no longer dominant, but more emphasis on two-way interaction between teacher and student. The learning process will be better if there are more tangible interactions between students and teachers. It is also hoped that teachers can design learning that exists from an early age with the environment in the educational environment to achieve the goals set (Sapta, 2018). The learning process in the 2013 curriculum requires students to actively participate and provide sufficient space for students' creativity, interests, and talents. Technology also became the main focus of the 2013 curriculum (Fitri, 2019).

According to Irwanto (2017) there are several reasons why teachers do not use learning media. The first reason is (1) The teacher considers that using media requires preparation. (2) Media is a sophisticated and expensive item. (3) Unusual use of media (technology stuttering). (4) Media is only for entertainment, while learning must be serious. (5) At the school the media is not available, the school does not have the equipment and materials to make learning media. (6) The teacher does not understand the importance of using instructional media. (7) Teachers do not have the knowledge and ability on how to make their own learning media. (8) Teachers do not have the skills to use learning media. (9) The teacher does not have the opportunity (time) to create learning media. 
(10) Teachers are used to relying on the lecture method.

Improving learning outcomes, as planned, requires improvements in the learning process. A quality learning process is a must. The government has designed various efforts to improve the quality of human resources in Indonesia. One step is to develop learning tools carried out by Putri et al. which can improve student learning outcomes by $85 \%$ (Syahputra, 2019).

According to Riyana in Asyhar (2011) through media, a learning process can be more interesting and enjoyable. This is emphasized from the opinion Asyhar (2011) which says that learning media as a learning resource is a component of the learning system that includes messages and information, which can affect student learning outcomes.

The reality on the ground shows that the use of information and communication technology has not been implemented properly by the teacher. This is proven by the results of observations made at SMA Negeri 1 Batang Kuis through an interview with one of the teachers at the school. He said that the facilities and infrastructure available at the school were very adequate, such as the availability of several projectors, laptops, and computer laboratories. Computer laboratories in these schools are only used when ICT subjects are rarely integrated into other subjects, especially in mathematics.

The teacher only uses textbooks when teaching. The use of instructional media in accordance with technological developments using computers is rarely applied by teachers. Computers can make abstract concepts concrete with static visualization and dynamic visualization. In addition, computers can make a concept more interesting, so students are motivated to follow the learning process. This is also in line with the opinion Batubara (2017) which states that one very important factor in influencing student learning processes is the presence of learning media.

Through observation, the researcher sees that the teacher teaches only using print media which causes students to feel bored. Students often have difficulty in understanding conventional material delivered by the teacher, because the information obtained is still said to be abstract or less tangible and limited to memorizing formulas. This is in line with research Surya (2010) which states that learning mathematics must be made with an exciting and fun strategy so that learning objectives can be achieved.

The results of interviews and observations during the learning process take place it can be concluded that the teacher does not yet have the skills to develop learning media by utilizing available school facilities. Teachers tend to only use print media so that makes students less enthusiastic and less motivated in learning because the ongoing learning process only uses textbooks. The use of media in the learning process in mathematics can be said to be not optimal.

The use of media in the form of software helps the effectiveness of the learning process and the delivery of information in the early stages of learning. Visually, students' senses will be more active during the learning process because students can develop material directly in the form of software in accordance with the material being studied. One of the media products produced from the development of ICT is learning media based on Macromedia flash.

The use of instructional media in learning mathematics will certainly also help in improving students 'mathematical abilities, one of which is students' spatial ability. Spatial thinking is a collection of cognitive skills, which consists of a combination of three elements, namely the concept of space, a tool of representation, and the process of reasoning (National Academy of Science, 2006).

Spatial ability is basically a type of reasoning based on the use of imagining. Spatial ability can look at a building from a different perspective is an abstract material for students. In general, every person has the spatial ability but can be distinguished when a person's spatial ability is low, it will get difficulties in certain things, for example parking, a car will often experience difficulties, it takes a long time when learning to ride a bicycle. Spatial ability also influences a painter in creating his work, just as an architect who has good spatial ability will be able to make a beautiful building design. It turns out that spatial ability is widely used in daily life. As is the case with Linda Campbell in Januariyansah (2015) that spatial intelligence instills the ability to think in three-dimensional ways as do seamen, pilots, sculptors, painters, and architects. The ability of spatial intelligence is very useful for finding information in visual form.

This refers to the opinion of Barke in Syahputra (2013) who argues that spatial ability is a major intelligence factor that is not only important for mathematics and science but is also necessary for success in many professions. Gadner in Syahputra (2013) who basically wrote that children need spatial abilities in exploration activities, for example when children paint, color, stick, play folding paper, and others.

Aspects of spatial ability consist of (1) Spatial visualization is the ability to manipulate objects in imaginary 3-D space and make representations of objects from new perspectives (Strong and Smith, 2002). (2) Spatial perception is the ability to observe a building or parts of a building that are placed in a horizontal or vertical position. The mental process of spatial perception is static, meaning that the relationship between subject and object changes, whereas the relationship between objects does not change (Yulianto, 2016). (3) Spatial relations is the ability to involve quickly and accurately in mental transformation or rotation processes for the assessment 
of the identity of a pair of stimuli (Canturk-Gunhan, 2009). (4) Spatial orientation is the ability to enter into certain spatial situations, for example guessing the results of photographs of objects that are photographed from a certain angle (Pratiwi, 2014). (5) The mental rotation includes the ability to rotate a room quickly and precisely (Yulianto, 2016). (6) Disembedding is the ability that allows one to find simple objects when inserted in more complex forms (Velez, 2005).

It can be concluded that spatial ability is the ability to visualize images, which includes the ability to recognize shapes and objects precisely, make changes in an object in his mind and recognize these changes, describe a thing or object in mind and change it in real form, expressing data in an graphics and sensitivity to balance, relations, colors, lines, shapes, and spaces. This is one of the spatial indicators needed in terms of orientation and visualization.

Studying geometry is very important because geometry has become the main tool for teaching the art of thinking. Geometry material is one material in mathematics that uses elements of visualization, spatial reasoning, and modeling. Geometry is a basic knowledge that has been introduced to children at an early age. In line with the opinion of the NCTM curriculum in Indonesia requires children to master the material geometry of the field and the geometry of space in which there is also spatial ability (Siswanto, 2017).

A disturbance in understanding the concepts of relationship relationships can interfere with students' understanding of the whole number system. To learn mathematics, students need not only master the concept of spatial relationships, but also other basic concepts to understand geometrical objects or shapes.

Students find it difficult to imagine visually in solving geometry problems. This is supported by the results of an interview with one of the teachers at SMA Negeri 1 Batang Kuis, who said that students still had difficulty understanding problems related to building space. Constraints include difficulties in visualizing images and providing an appropriate perception of images or geometry problems. Among them are several questions that emphasize the students' spatial ability.

Therefore we need an appropriate learning activity to be able to improve students' spatial abilities, including by utilizing learning media with the help of Macromedia Flash to be able to describe geometric shapes in real contexts.

Likewise stated in research Ristontowi (2013) states that the spatial ability of students taught by using learning media is better than students who are taught without using learning media. Another study from Pranawestu (2012) also mentioned that the spatial ability of students with learning media assistance reached the value of minimal completeness criteria and was also better than students who were taught without the aid of learning media. Therefore, we need an appropriate learning activity to be able to improve students' spatial abilities, including by utilizing learning media.

The purpose of the researchers writing this article is to find a valid, practical, and effective mathematics learning media to be able to improve students' mathematical spatial abilities developed based on Macromedia Flash.

\section{Research Methods}

This research was carried out at SMA Negeri 1 Batang Kuis in the odd semester of the Academic Year 2019/2020. The subjects in this study were students of class XII MIA-1 and XII MIA-2 SMA Negeri 1 Batang Kuis, while the object in this study was a learning media based on Macromedia Flash mathematics on Three Dimensions material.

\subsection{Learning Media Development Procedure}

This type of research is Research and Development. The development of instructional media that will be carried out in this study is based on the Thiagarajan development model Thiagarajan (1974) which is also known as the "Four-D Model" or the 4-D model which includes four stages of development, namely: Define, Design, Develop, and Disseminate.

In the development of educational products, the quality of product development has an important role in the world of education as expressed by Nieveen (1999) namely "the wide array of educational products that play important roles in education". Furthermore, the quality of learning development products must meet valid, practical and effective criteria (Nieveen, 1999).

This learning media is said to be feasible if the learning media have fulfilled the valid, practical and effective criteria. The validity used in the questionnaire instrument to construct validity. The questionnaire instrument is said to be valid if it has been approved by the experts. The following are the validity criteria for learning media: 


\begin{tabular}{ccc}
\multicolumn{3}{c}{ TABLE 1. LEARNING MEDIA VALIDITY CRITERIA } \\
\hline NO & Va or total average value & Validity Criteria \\
\hline 1 & $1 \leq \mathrm{Va}<2$ & Invalid \\
\hline 2 & $2 \leq \mathrm{Va}<3$ & Invalid \\
\hline 3 & $3 \leq \mathrm{Va}<4$ & Valid enough \\
\hline 4 & $4 \leq \mathrm{Va}<5$ & Valid \\
\hline 5 & $\mathrm{Va}=5$ & Very Valid \\
\hline
\end{tabular}

(Sinaga, 2007)

Learning media are said to be practical if: (1) the validator states that learning media are well developed and can be used with little or no revision; (2) the teacher questionnaire states that the learning media developed are easy to use/run; (3) students' responses to learning media developed positively; (4) the level of completeness of the Group Worksheet at each meeting that reaches $50 \%$ or more than half of the group completed.

Learning media is said to be effective if: (1) the achievement of classical students' mastery learning is at least $85 \%$ of the total number of students who take part in learning using Macromedia flash media has good spatial ability, namely a minimum score of 12.51 or a minimum predicate B-; (2) the time spent in learning is efficient or does not exceed ordinary learning.

To find out the increase in spatial ability, the data was obtained from the results of the pretest and posttest spatial ability in each trial. Improved students' spatial ability can be obtained from normalized gain index data as follows:

$$
N-\text { Gain }=\frac{\text { postes }- \text { pretes }}{\text { skor ideal }- \text { pretes }}
$$

TABLE 2 NORMALIZED GAIN INDEX CRITERIA $(\mathrm{g})$

\begin{tabular}{lc}
\hline Skor Gain & Category \\
\hline $\mathrm{g}>0.7$ & High \\
\hline $0.3<\mathrm{g} \leq 0.7$ & Medium \\
\hline $\mathrm{g} \leq 0.3$ & Low \\
\hline
\end{tabular}

(Hake, 1999)

\section{Results}

\subsection{Description of learning media development results}

In this research development, learning media based on Macromedia flash has met the effective criteria after a trial II which produced the final draft. The results of the development of the 4-D model learning media are explained as follows:

\subsubsection{DEFINE}

Based on observations of learning media in SMA Negeri 1 Batang Kuis shows that the use of information and communication technology has not been implemented properly by teachers. The teacher has not yet fully made learning media an interesting thing for students. On average each teacher still uses media that are monotonous, not moving (no animation), even there are still some teachers who have not used instructional media as a means of the teacher teaching in class. An interview was also conducted with one of the mathematics teachers showing that there were still many students whose test scores had not yet reached the KKM $(\geq 75)$. The teacher said that some students did not really like mathematics, it was seen when the teacher taught in class, many students looked bored and did not understand what was explained by the teacher in front of the class, so this affected student learning outcomes which resulted in the low students' mathematical spatial abilities. The low mathematical spatial ability of students is inseparable from the teacher's role in managing learning. In the learning process, the teacher tends to transfer the knowledge possessed to students' minds, prioritizing the results rather than the process. This is the cause of students' mathematical spatial ability is still low.

\subsubsection{DESIGN}

At this stage an initial draft of the learning media is produced, a learning implementation plan, a group worksheet for each meeting, a student's spatial ability test, a teacher response questionnaire, and a student response questionnaire. All results at this design stage are called draft 1 . All of the initial designs are adapted to Macromedia Flash-assisted media so that they become a single entity so that its application is expected to have an impact on improving the mathematical spatial abilities of students at SMA Negeri 1 Batang Kuis.

\subsubsection{DEVELOP}

After Macromedia Flash-assisted learning media is designed in the draft I, a validity test is carried out on the expert/expert and then a field trial is conducted. The aim is to correct the errors and weaknesses of the design results (draft I) which are then used as a basis for revision and refinement of the initial design of learning. Based on the sheet that has been validated by the validator it is found that all the preliminary learning designs developed have met the valid criteria, with a total average value of learning media validation by learning material experts at 
4.5, validation of learning media by learning media experts at 4.61, RPP validation is 4.32, and Group Worksheet is 4.22. Students' spatial ability tests that have been revised from an expert validator are then trialed to students outside the research sample. All items of students' spatial ability tests are valid and reliable. After calculation, the reliability of the spatial ability test was 0.841 (very high category).

After the learning media developed has met the validity criteria (draft II), then the learning media in the form of draft II was tested at the research site, namely class XII of SMA Negeri 1 Batang Kuis, hereinafter referred to as trial I. Trial I was conducted in class XII MIA-1 with a total of 36 students. Trial I was conducted to measure the practicality and effectiveness of the learning media (draft II) that was developed which aims to improve students' spatial abilities.

Overall, the results of the analysis of trial I data are that the developed media has fulfilled all the practical criteria, but has not yet fulfilled the established effective criteria, that is, the results of the posttest of the spatial ability of students in a trial I have not met the criteria for achieving mastery classically.

Based on the results of the analysis and trial I, it is necessary to revise the learning media developed in the hope that Macromedia Flash-based learning media can improve students' spatial abilities. The results of the trial I used as a reference to improve the learning media developed.

The revised results of trial I produced draft III which will be tested on students of class XII MIA-2, amounting to 36 students. Trial II was conducted to measure the effectiveness of instructional media (draft III) which was developed which aims to improve students' spatial abilities.

Overall, the results of the analysis of the trial II data are that the learning media developed have been effective, such as the results of the posttest students' mathematical creative thinking abilities in the second trial have met the criteria of achieving classical completeness and the achievement of learning time not exceeding normal learning has been achieved.

Thus, it is known that the results of trial II are better than trial I, then based on the results of trial II it can be concluded that learning media based on Macromedia Flash has met the quality of practical and effective mathematics learning media.

\subsubsection{DISSEMINATE}

The development of learning media has reached the final stage where learning media have received positive assessments from experts and through development tests. The dissemination phase in this study was limited to only partner schools, namely class XII of SMA Negeri 1 Batang Kuis on Dimension Three.

\subsection{TRIAL RESULTS}

\subsubsection{TRIAL RESULTS I}

Validity analysis of learning media supported by Macromedia flash developed from two aspects, namely the assessment of experts/practitioners of learning media and experts/practitioners of mathematics subjects. The results of the validator showed that the learning media developed were valid. For more details, see Table 3 below:

\begin{tabular}{|c|c|c|}
\hline Validator & Average & Criteria score \\
\hline $\begin{array}{l}\text { Mathematics learning } \\
\text { media expert }\end{array}$ & 4,5 & Valid \\
\hline $\begin{array}{l}\text { Expert subject matter in } \\
\text { mathematics }\end{array}$ & 4,61 & Valid \\
\hline
\end{tabular}

Based on the data in Table 3, the interpretation of each media expert and mathematic subject matter expert is in the valid category. Thus, Macromedia Flash-assisted learning media can be said to be feasible to use.

Description of the effectiveness of Macromedia Flash-assisted mathematics learning media developed in trial 1 as follows:

A. CLASSICALLY COMPLETION RESULTS STUDENTS' SPATIAL ABILITY

A description of the results of students' spatial ability in the first try is shown in Table 4.

TABLE 4. CLASSICAL LEVEL OF MASTERY SPATIAL ABILITY OF TRIAL STUDENTS I

\begin{tabular}{lcccc}
\hline \multirow{2}{*}{ Category } & \multicolumn{2}{c}{ Pretest } & \multicolumn{2}{c}{ Posttest } \\
\cline { 2 - 5 } & Number of Students & Percentage & Number of Students & Percentage \\
\hline Complete & 20 & $55,56 \%$ & 28 & $77,78 \%$ \\
\hline Not complete & 16 & $44,44 \%$ & 8 & $22,22 \%$ \\
\hline Average & 58,33 & & 66,67 & \\
\hline
\end{tabular}

For more details can be seen in the following diagram: 
Trial I

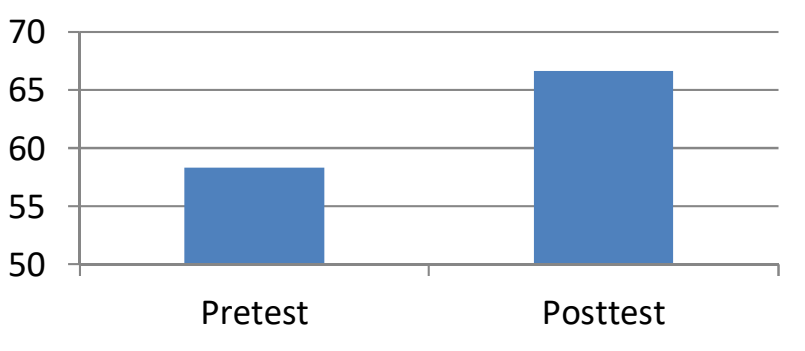

FIGURE 1. AVERAGE VALUE IN TRIAL I

Based on Figure 1 shows that the average value of the spatial ability of students in pretest I tryout is 58.33 while the average value at the posttest is 66.67 .

\section{B. TRIAL LEARNING TIME ACHIEVEMENT I}

Based on research that has been carried out in trial I in class XII MIA-1 SMA Negeri 1 Batang Kuis, the use of time to teach three-dimensional material using Macromedia flash-based media is in accordance with the learning implementation plan made by researchers, namely the learning time carried out the same as the learning time as usual so that it can be said that the research using the learning media supported by Macromedia flash which has been developed has a good time achievement.

Increased spatial ability in the first trial will be seen through N-Gain from the results of the pretest and posttest mathematical creative thinking abilities in the first try. The average pretest score is 58.33 and the average post-test 66.67 so that the $\mathrm{N}$-gain value is as follows :

$$
N-\text { gain }=\frac{66,67-58,33}{100-58,33}=\frac{8,34}{41,67}=0,20
$$

\subsubsection{TRIAL RESULTS II}

A. CLASSICALLY COMPLETION RESULTS STUDENTS' SPATIAL ABILITY

A description of the results of students' spatial ability in trial II is shown in Table 5.

TABLE 5. CLASSICAL LEVEL OF MASTERY SPATIAL ABILITY OF TRIAL STUDENTS II

\begin{tabular}{lcccc}
\hline \multirow{2}{*}{ Category } & \multicolumn{2}{c}{ Pretest } & \multicolumn{2}{c}{ Posttest } \\
\cline { 2 - 5 } & Number of Students & Percentage & Number of Students & Percentage \\
\hline Complete & 26 & $72,22 \%$ & 31 & $86,11 \%$ \\
\hline Not complete & 10 & $27,78 \%$ & 5 & $13,89 \%$ \\
\hline Average & 59,17 & & 77,5 & \\
\hline
\end{tabular}

For more details can be seen in the following diagram:

\section{Trial II}

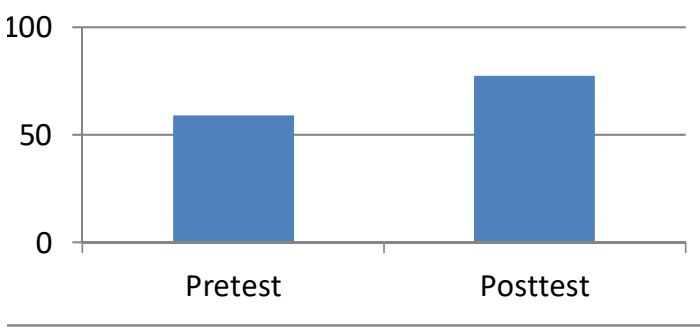

FIGURE 2. AVERAGE SCORES IN TRIAL II

Based on Figure 2 shows that the average value of the spatial ability of students in the pretest II trial is 59.17 while the average value at the posttest is 77.5 .

From Table 4 it can be seen that the results of classical completeness of the spatial ability of students in pretest II tryouts were $72.22 \%$ while the results of classical completeness of students' spatial ability at posttest II were $86.11 \%$. In accordance with the criteria of mastery learning students classically, which is at least $85 \%$ of students who take the test of the ability to think creatively classically. So it can be concluded that in the second trial the learning media of Macromedia flash-assisted mathematics learning developed met the classical completeness criteria.

Increased spatial ability in the second trial will be seen through the N-Gain from the results of the pretest and posttest mathematical creative thinking abilities in the second trial. The average pretest value is 59.17 and the posttest average is 77.5 so the $\mathrm{N}$-gain value is as follows: 


$$
N-\text { gain }=\frac{77,5-59,17}{100-59,17}=\frac{18,33}{40,83}=0,45
$$

Based on the normalized gain index $(\mathrm{g})$, it was found that in a trial I the value with a low criterion $(\mathrm{g} \leq 0.3)$ and in trial II there was an increase in the value with a moderate criterion $(0.3 \leq \mathrm{g} \leq 0.7)$.

\section{Discussion}

Based on the results of the analysis in trials I and II it was found that the spatial ability of students had met the classical completeness criteria. This is caused by the material and problems that exist in the mathematics learning media developed from group worksheets in accordance with real problems in life. By using instructional media in the classroom, students will better understand the concept of three dimensions. This is supported by Handayani (2019) which states that students' mathematical visual thinking abilities can be improved by using Macromedia flash-assisted learning media. The existence of Information and Communication Technology can provide a new nuance to encourage a better process of learning mathematics. This is in line with research Siregar (2019) which also revealed that Adobe Flash-assisted mathematics learning media can improve students' spatial abilities.

The spatial ability of students can be increased because learning media based on Macromedia flash is applied to students who have met the criteria for good quality learning media, learning media is also easy to use in the learning process.

This means that using learning media when the teaching and learning process takes place can improve students' spatial ability. Based on the results of research that has been done also based on the results of previous relevant studies, it can be concluded that the learning media based on Macromedia flash mathematics developed has a positive impact on students' spatial abilities.

\section{Conclusions}

The results showed that the learning media based on Macromedia flash fulfilled valid, practical and complete spatial ability criteria which reached $86.11 \%$ and the learning time was not much different from the usual learning time.

\section{Acknowledgment}

On this occasion the authors would like to express their sincere thanks and highest appreciation to all those who have helped the author: Mr. Prof. Dr. Edi Syahputra, M.Pd as the supervisor I and Chair of the Mathematics Education Postgraduate Study Program, Mr. Prof. Dr. Sumarno, M.Pd as the supervisor II, Mr. Adi Sumarno, S.Pd as the Principal of SMA Negeri 1 Batang Kuis who has given permission and the opportunity for the writer to conduct research in the school he leads, as well as teachers and administrative staff who has helped many writers in conducting this research.

\section{REFERENCES}

Asyhar, R., "Creative Developing Learning Media", Jakarta: Gaung Persada (GP) Press Jakarta, 2011.

Batubara, H. H., "Development of Android-Based Mathematics Learning Media for Elementary / MI Students", MUALLIMUNA: Journal of Madrasah Ibtidaiyah, vol. 3, no. 1, p. 12-27, 2017.

Canturk-Gunhan, B., Turgut, M. and Yilmaz, S., "Spatial Ability of A Mathematics Teacher: The case of Oya. This Paper Presented as a Poster at the Sixth Conference of European Research in Mathematical Education", IBSU Scientific Journal, vol 3, no. 1, p. 151-158, 2009.

Fitri, S., Syahputra, E., \& Syahputra, H., "Blended Learning Rotation Model of Cognitive Conflict Strategy to Improve Mathematical Resilience in High School Students", International Journal of Scientific \& Technology Research, vol.1, no. 1, 2019.

Hake. Analyzing Change/ Gain Scores, Woodland Hilis: Dept. of Physics, Indiana University. 1999.

Handayani, T. W., Syahputra, E., \& Mulyono, "Media Development Model-Based Learning Detection Assisted Guided Macromedia Flash for Improving the Visual Thinking Ability of Junior High School Students", Journal of Education and Practice, vol. 10, no. 20, 2019.

Irwanto, M. Z., "Development of Learning Media for Building Material Flat Side Space Using Macromedia Flash Applications 8", MATHEdunesa Mathematical Education Scientific Journal, Vol. 2. No. 6, 2017.

Januariyansah, S., and Ngadiyono, Y., "Relationship of Spatial Intelligence and Technical Image Understanding of the Ability to Apply Autocad", Journal of Mechanical Engineering Vocational Education, vol. 3, no. 4, p. 225-232, 2015.

Marliani, N., "Improving Students' Mathematical Creative Thinking Abilities through the Missouri Mathematics Project (MMP) Learning Model", Formative Journal, vol. 5, no. 1, p. 14-25, 2015.

National Academy of Science, "Learning to Think Spatially", Washington DC: The National Academy Press, 2006.

Nieveen, N., "Prototype to reach product quality. In van den Akker, J., Branch, R.M., Gustafson, K., Nieveen, N., \& Plomp, T. (pnyt) ". Design approaches and tools in education and training. Dordrecht: Kluwer Academic 
Publisher, 1999.

Pranawestu, A., Kharis, M. and Mariani, S., "Effectiveness of Character-Based Problem Based Learning in Character-Based Cabri Against Spatial Capabilities”, Unnes Journal of Mathematics Education, Vol. 1 No. 2, 2012.

Pratiwi, F. A., Mardiyana, and Subanti S., "Experimentation of the Team Assisted Individualization (TAI) Type of Cooperative Learning Model with Assessment for Learning (AFL) in Material Space Drawings in terms of Spatial Capability of Grade VIII Public Middle Schools in Karanganyar Regency", Electronic Journal of Mathematics Learning, Vol.2, No.8, p. 842-852, 2014.

Ristontowi, "Spatial Ability of Students Through Indonesia's Realistic Mathematics Education Approach with Geogebra Media", Proceedings of the ISBN: 978-979-16353-9-4. Mathematics Education FMIPA UNY, Yogyakarta, 2013.

Sapta, A., Hamid, A., \& Syahputra, E., “Assistance of Parents In The Learning At Home”. IOP Conf. Series: Journal of Physics: Conf. Series 1114 (2018) 012020 DOI:10.1088/1742-6596/1114/1/012020.

Sinaga, B. Development of Mathematical Learning Models Based on Problems Based on Batak Culture (PBMB3). Dissertation. Surabaya State University Graduate Program. 2007.

Siregar, M. U. M., Syahputra, E., \& Sriadhi, "The Development of Cooperative Type-Based Learning Media of STAD Assisted by Adobe Flash to Improve Spatial Ability of Students in Medan 1 MTs Negeri 1 Model”, Journal of Education and Practice, vol. 10, no. 21, 2019.

Siswanto, R. D., and Kusumah, Y. S., "Improving the Spatial Geometry Ability of Middle School Students Through Guided Inquiry Learning with Geogebra Assistance", Journal of Mathematics Research and Learning, vol. 10, no. 1, 2017.

Strong, S. and Smith, "Spatial Visualization: Fundamentals and Trend In Engineering Graphics", Journal of Industrial Technology. Vol 18, no. 1, 2002.

Surya, E., "Visual Thinking in Maximizing Mathematics Learning Students Can Build Nation's Character", Journal of Mathematics Research and Learning, vol. 10, no. October 10, 2010.

Syahputra, E., \& Utami. D. R., "The design of the IQF-oriented ARCS-based learning model", International Seminar on Applied Mathematics and Mathematics Education 2019: IOP Conf. Series: Journal of Physics: Conf. Series 1315 (2019) 012065, 2019, DOI: 10.1088 / 1742-6596 / 1315/1/012065.

Syahputra, E., "Increasing Students' Spatial Ability through the Application of Realistic Mathematics Learning", Journal of Educational Horizon No. 3, 2013.

Tafanao, T., "The Role of Learning Media in Increasing Student Learning Interest. Journal of Educational Communication", Vol. 2, No. 2, p. 103-114, 2018.

Thiagarajan, S., Semmel, D., \& Semmel, M. "Instructional Development for Training Teachers of Exceptional Children", Indiana: Indiana University Bloomington, 1974.

Velez, M. C., Silver, D., and Tremaine, M., "Understanding Visualization Through Spatial Differences", IEEE Xplore Digital Library, Vis 05, p. 511-518, 2005.

Yulianto, T., "Analysis of Spatial Ability of Students in Kesatrian 1 Junior High School in terms of Cognitive Style in Problem-Based Learning Settings”, Thesis UNNES, 2016. 